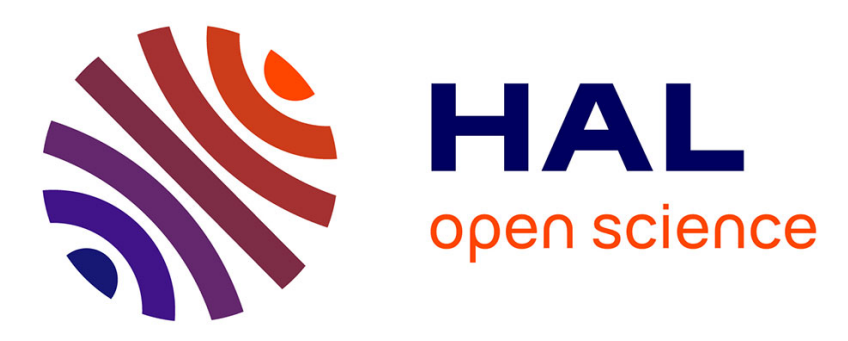

\title{
Investments of the Automotive Sector and the Industry 4.0. Brazilian Case
}

Sergio Miele Ruggero, Nilza Santos, José Benedito Sacomano, Marcia Terra da Silva

\section{> To cite this version:}

Sergio Miele Ruggero, Nilza Santos, José Benedito Sacomano, Marcia Terra da Silva. Investments of the Automotive Sector and the Industry 4.0. Brazilian Case. IFIP International Conference on Advances in Production Management Systems (APMS), Sep 2019, Austin, TX, United States. pp.650657, 10.1007/978-3-030-30000-5_79 . hal-02419238

\section{HAL Id: hal-02419238 \\ https://hal.inria.fr/hal-02419238}

Submitted on 19 Dec 2019

HAL is a multi-disciplinary open access archive for the deposit and dissemination of scientific research documents, whether they are published or not. The documents may come from teaching and research institutions in France or abroad, or from public or private research centers.
L'archive ouverte pluridisciplinaire HAL, est destinée au dépôt et à la diffusion de documents scientifiques de niveau recherche, publiés ou non, émanant des établissements d'enseignement et de recherche français ou étrangers, des laboratoires publics ou privés. 


\title{
Investments of the Automotive Sector and the Industry 4.0. Brazilian Case.
}

Sergio Miele Ruggero 1[0000-0002-2370-2238], Nilza Aparecida dos Santos ${ }^{1,2}$ [0000-0001-9037${ }^{0686]}$, José Benedito Sacomano ${ }^{10000-0002-4877-3139]}$, Marcia Terra da Silva ${ }^{1[0000-0002-5314-}$ 4978].

${ }^{1}$ Graduate Studies in Production Engineering - Universidade Paulista, São Paulo SP 04026002, Brazil miele326@gmail.com nilzaasantos7@gmail.com jbsacomano@gmail.com marcia.terra@uol.com.br ${ }^{2}$ FATEC Cotia. 06702-155, SP, Brazil nilzaasantos7@gmail.com

\begin{abstract}
This text deals with the nature of the investment of companies of the Brazilian automotive sector to suit the Industry 4.0. The data were collected through a survey applied to executives of this segment, through the observational method and bibliographic research. The results show that the participants are aware of the need for investments for the proposed adequacy and productivity gains, but that this volume of investment is still not enough for a robust modification. The importation of technology is not portrayed as fundamental, where the level of investment required in addition to the lack of training of the labor force, are impeding factors for the evolution of the Industry 4.0. It was observed that due to the economic crisis that has taken place in Brazil, the automotive industry has focused on the survival in the market under current conditions rather than strategies for investment in Industry 4.0 technology.
\end{abstract}

Keywords: Investments, Connectivity, Industry 4.0, Technology, Automotive.

\section{Introduction}

The technological advance provides an important range of knowledge and relational competence in the production chain, in addition to pointing to one of the main pillars of the evolution of production processes and economic growth. The continuous process of technological improvement has provided qualitative "leaps" for the industries in general. In contrast to the productive models resulting from the first Industrial Revolution, which took the steam engine as the driving force of the production system and the circulation of goods and services, the manufacture and use of Information Technology were in the following century concomitantly as second and third industrial revolution as a result of the complexity of the productive system [1].

In this sense, the twenty-first century suggests a new mode of production by establishing the need for connectivity. What is at issue when it comes to connectivity is precisely the production infrastructure that joins together the Technology of Operation (TO) and Information Technology (IT), using tools capable of ordering a mass of data, ideas and associated things, so that the human element occupies a central but 
not centralizing position in this process, since machines and computers cannot have ideas of autonomous form [2].

It is interesting in this case to explore how the contribution of new technologies is associated with the automotive industry in the context of the Brazilian market in relation to investments. The assumption is that technological innovation on the national scene becomes a competitive element that does not completely unlink the human workforce and that the realization of investments is fundamental in the search for competitiveness and superior performance. Given the needs and investment conditions of the automotive industry in Brazil, the issue is: how organizations in the automotive segment prioritize investments in the industry 4.0. The objective of this study was to analyze the nature of the investment of companies in the automotive sector to fit the Industry 4.0.

\section{$2 \quad$ Literature Review}

Industry 4.0 is an integral concept of the Fourth Industrial Revolution. The idea is that it manages the integration of Cyber-Physical System (CPS), joining the real with the virtual and connecting digital, physical and biological systems, raising personalized mass production [3]. It is based on nine pillars: big data, autonomous robots, simulation, vertical and horizontal integration systems, internet of things, cyber-physical systems, cloud, additive manufacturing or 3D printing and augmented reality [4], among those cited the most representative is the horizontal and vertical integration of the systems that portrays the industrial base in relation to the administration and the interdependence between the companies [5].

Four elements (types of intelligence) are highlighted for the transition to Industry 4.0, they are: Smart Manufacturing that seeks to transform the most intelligent and advanced machine through new technologies; Smart Products and Services, which deals with the connectivity of digital products and services, by opting for the communication and data collection between companies and clients; Smart Working, which uses technologies to improve work efficiency; and the Smart Supply Chain, represented by external integration in the value chain. However, for these fundamentals to be a part of Industry 4.0, they need to be supported by the internet of things and more advanced technologies, generating connectivity and more efficient business systems [6].

Intelligent factories, designed as the core of Industry 4.0, operate in an integrated network. Four characteristics are highlighted: the vertical integration of intelligent production systems; horizontal integration through networks and the global value chain; engineering across the value chain and acceleration through exponential technologies [7]. Connectivity can hardly be considered something new, the ease in achieving this connectivity is that it presents itself as innovative, impacting on general manufacturing operations, corroborating with other studies [6] on 04 elements of intelligence, highlighting the importance of new technological tools as a source of connectivity in enterprise systems.

Recognized as the next phase of manufacturing, Industry 4.0 applies digitization in its processes and is leveraged by disruptive technologies such as increased data volume 
by computational capacity and connectivity; the possibility of data analysis by market intelligence sectors; new models of interaction between man and machine; improved transfer of digital commands to the physical environment [8]. The use of these technologies and the application of artificial intelligence techniques, allow a greater understanding of the shop floor, facilitating the planning of the predictive maintenance with decrease of failures and increase the efficiency in productive processes [9]. Continuous monitoring of the condition of production assets provides reliable data for performing predictive maintenance planning in anticipation of problems and avoiding losses.

It should be emphasized that the fourth industrial revolution goes far beyond the innovative technologies employed, since they contribute to the differentiation of companies in business management, knowledge management and training of workers able to participate in productive processes [3].

In Brazil, as well as in emerging markets, developments in industrial processes can be represented by the transition to Industry 4.0, requiring the investments that promote the adaptation of infrastructure and manpower capacity [10].

\section{Methods}

This research was exploratory, of a qualitative and quantitative nature, performed through interviews with executives from the industrial area, belonging to the automotive segment.

The primary data were collected through a survey sent to the managers and directors of the manufacturing area of assemblers and auto parts. Twenty-five questionnaires with 11 questions were addressed, emphasizing the knowledge about Industry 4.0, the priority regarding investments made in connectivity and the adaptation to new technologies.

The elaboration of the questions occurred based on the professional experience of the authors in the studied segment, based on observations in loco. For the respondents the questions were arranged in a random way and for the presentation of the results, grouped in 04 different figures. Figure 01 portrayed the interviewees' opinion regarding the knowledge about the theme, the positioning and the need of the segment to enter the Industry 4.0. Figure 02 the idea was to understand the nature of investments. Figure 03 addressed priority and relative gains. Figure 04, which dealt with the elements that may be necessary to the transition, being the same listed based on the resources used by automakers and auto parts.

Of the sample submitted, 21 questionnaires returned, of which $48 \%$ are large assemblers and $52 \%$ are medium-sized auto parts. Secondary data were collected through documentary analysis $[09,11,12]$ and bibliographic references. The observational method was used to calculate and analyze the results, considering the professional experience and participation of the authors in the segment. 


\section{$4 \quad$ Result and Discussion}

The results are presented by means of the figures below.

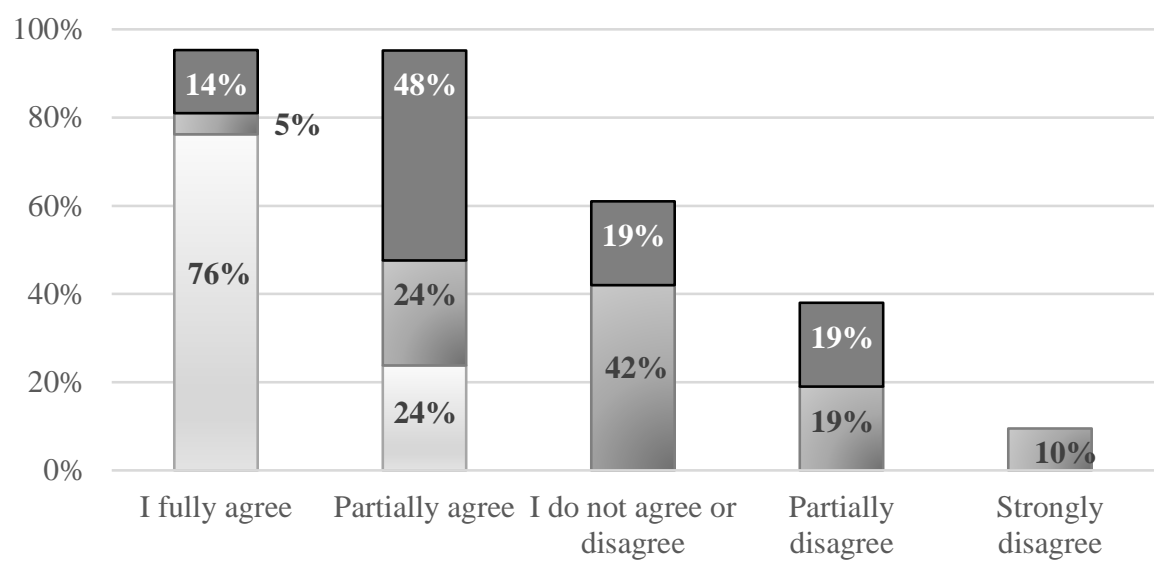

$\square$ All automotive companies need to be fully integrated with the Industry 4.0.

$\square$ Considering the investment capacity, the automotive industry is the industrial segment with the highest possibility of joining the Industry 4.0.

$\square$ You have knowledge about the Industry 4.0.

Fig. 1 - Source prepared by the authors

Figure 1 indicates that $100 \%$ claim to know about the issue, but they do not reiterate the automotive segment as the main driver of the Industry 4.0. Regarding integration $62 \%$ believe that all companies need to be integrated. It is noticed in the correlation of the answers and based on the observational method, that although the participants of the research claim knowledge on the subject, this understanding may be superficial considering the complexity of the subject and the impossibility of measuring the interpretation given by each interviewed. Secondary data [11] reveal the low knowledge industry users generally have about digital technologies and their benefits, stressing the need for greater dissemination on the subject. 


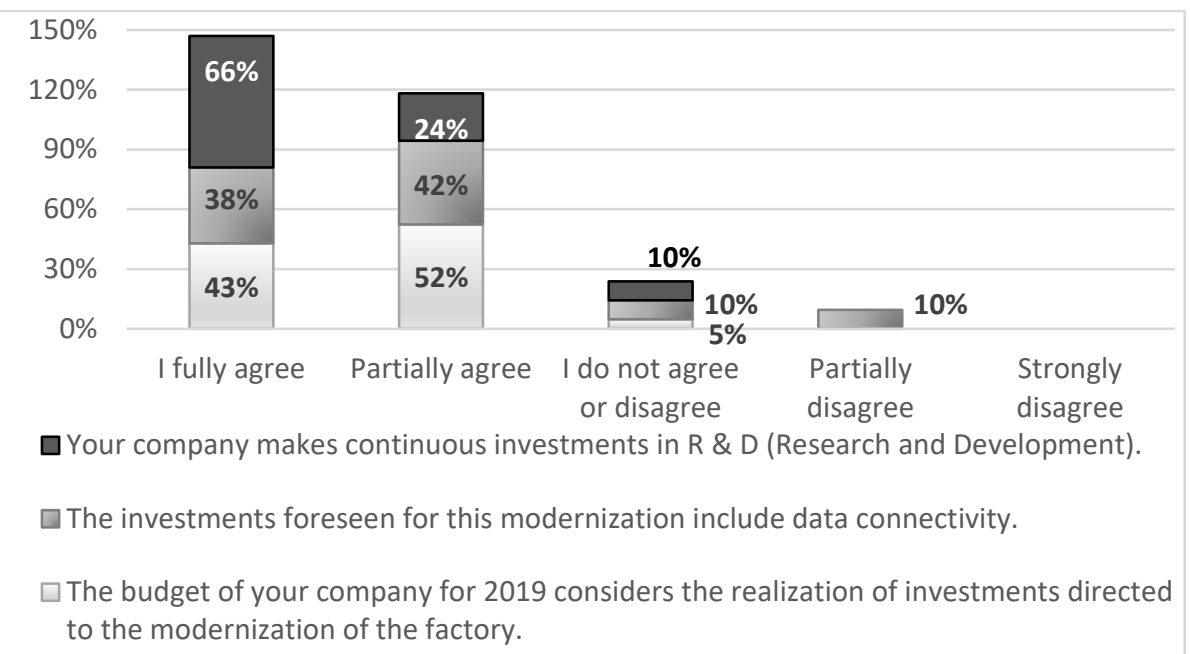

Fig. 2 - Source prepared by the authors

As shown in figure 2, companies invest in research and development and in the modernization of factories. Regarding connectivity, although the answers point in the same direction, a disagreement is observed, which may indicate that the investment volume for this issue occurs to a lesser extent, when compared to the others mentioned.

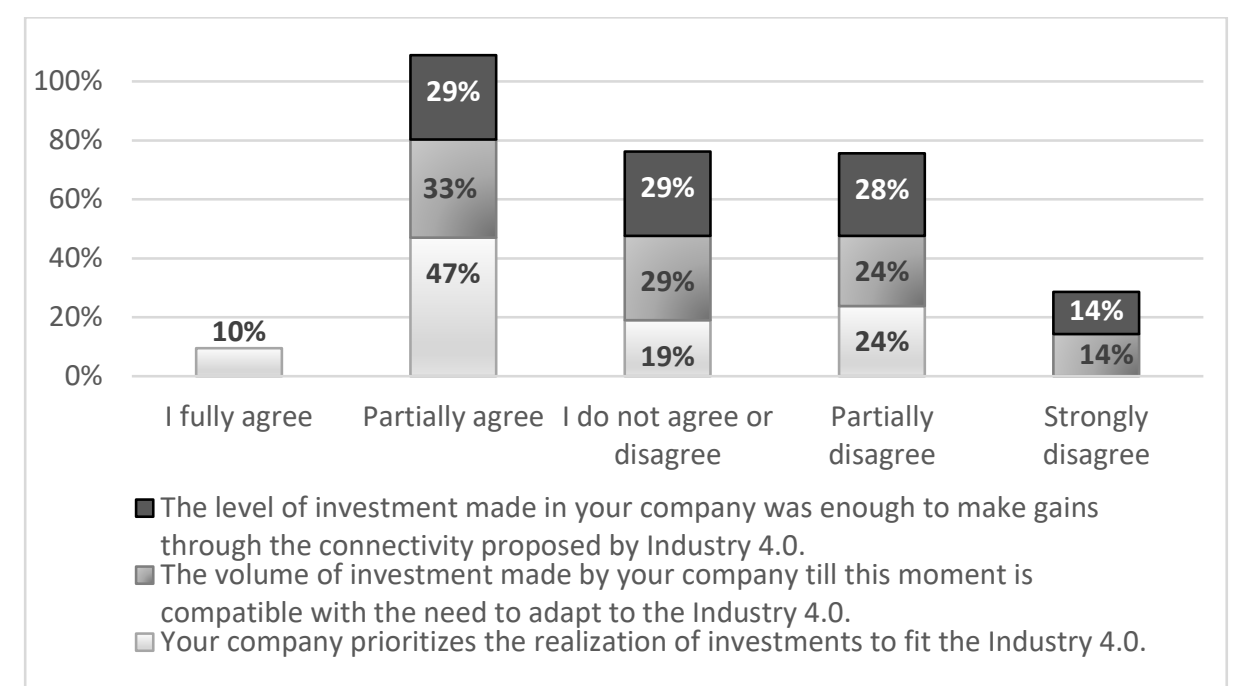

Fig. 3 - Source prepared by the authors

Figure 3 shows that companies partially prioritize investments and that the volume invested is neither compatible with the necessary nor enough to obtain gains from connectivity. 


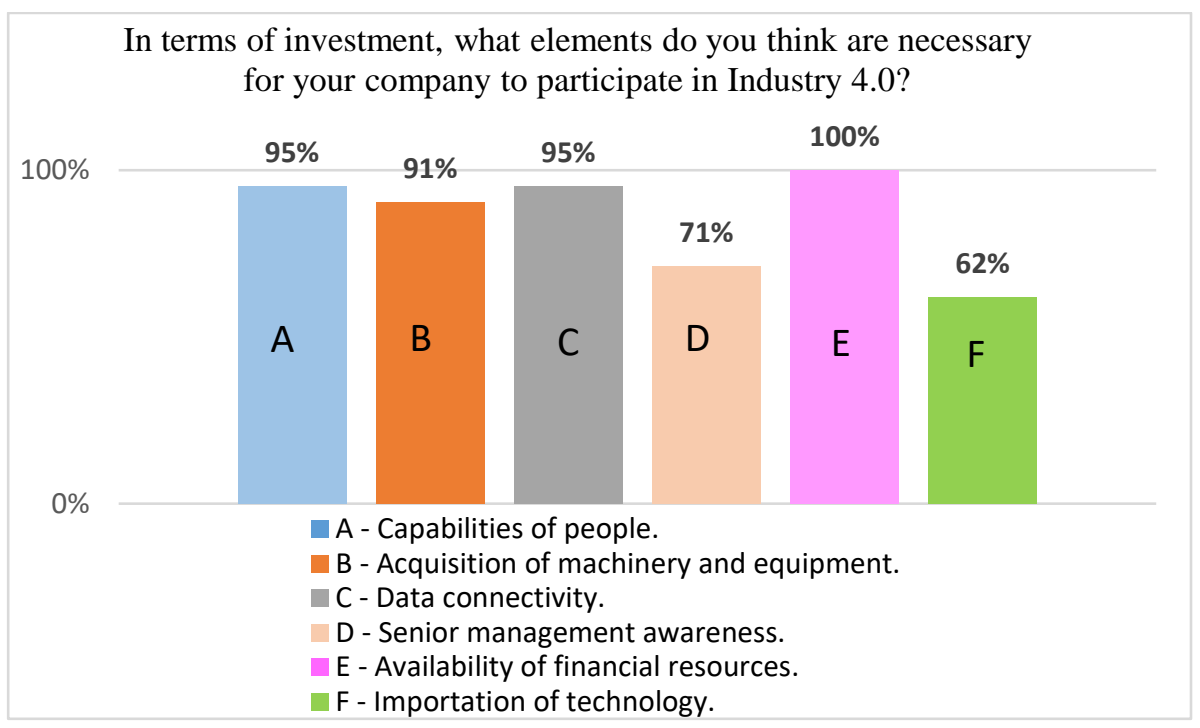

Fig. 4 - Source prepared by the authors

The elements portrayed in figure 4 were considered relevant for participation in Industry 4.0, with the importation of technology and awareness of top management less mentioned. It can be inferred, from these results, that the executives of these companies perceive the necessity of the realization of investment. The importation of technology has not been portrayed as fundamental, which based on responses and on the observational method can lead to the fact that the synergy between resources and training of manpower can result in the development of national technology.

Considering in general, companies in the automotive segment, what is your perception regarding the level of investment aimed at adapting them in terms of connectivity?

The reality of companies in Brazil does not allow investments in connectivity.

Few companies can make investments in connectivity.

The companies still do not care about investments in connectivity.

The level of investment is appropriate to the needs of companies.

The level of investment is insufficient.

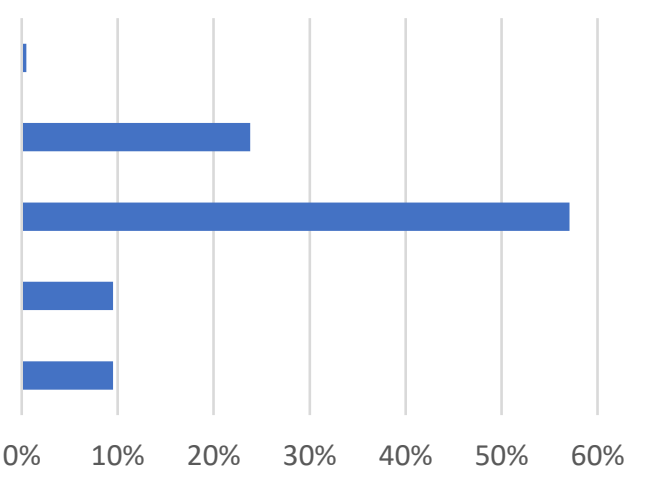

Fig. 5- Source prepared by the authors 
Considering what has already been portrayed and based on observations, the indication of the companies' lack of concern for investments in connectivity can be explained by the Brazilian economic crisis [12], which leads them to first seek survival in the market and then prioritize the investment in connectivity.

\section{Conclusion}

The objective of this study was to analyze the nature of the investment of companies of the automotive sector to fit the Industry 4.0. Based on the results of the survey applied to executives of the area, through the observational method and bibliographic research, it can be verified that the respondents know about the subject, understand that the integration of the companies is necessary, but they do not recognize this segment as main reference for the evolution of the Industry 4.0 in Brazil.

It was found that the budget of the companies surveyed contemplate investment for modernization, research and development and, to a lesser extent, connectivity. Although they prioritize investment, though in a partial way, the volume invested when compared to the needs is insufficient, including to obtain productivity gains from connectivity. This fact can be explained by the Brazilian economic crisis [12], which leads the automotive industry to favor survival in the market in current terms, instead of strategies to make more investments.

Thus, it can be said that the level of investment demanded, added with the lack of training of the labor force, are factors that impede the evolution of the Industry 4.0 in Brazil. However, studies [9] point out that the transition to Industry 4.0 is a necessary reality, which brings productivity gains and opens opportunities for national development and greater international competitiveness.

The present research does not allow definitive conclusions, due to the limitations inherent in the sample size. Despite being careful in presenting, analyzing and interpreting the data to ensure the results obtained, they can not be generalized to the universe of segments and companies, but they open up possibilities for future studies that may deepen the question of investments destined to the transition of Brazilian industry for the Industry 4.0.

"This study was financed in part by the Coordenação de Aperfeiçoamento de Pessoal de Nível Superior - Brasil (CAPES) - Finance Code 001"

\section{References}

[1] SACOMANO, J.B.; LIMA, A.W.B. [et al.]. Industry 4.0: concepts and fundamentals \& organization. São Paulo: Blucher, 2018. 
[2] ASHTON, K. That internet of things' thing. RFID Journal. Jun.22.2009. Disponible in: RFID journal-That\% 20Internet \%20of\%20 Things\%20 Thing.pdf. Access in: Jan.23.2019.

[3] SCHWAB, K. The Fourth Industrial Revolution. 1st Edition, World Economic Forum. Crown Business: New York. 2016.

[4] MOTYL B., BARONIO, G., UBERTI, S., SPERANZA D., FILIPPI, S. How will Change Engineer's Skills in the Industry 4.0 Framework? A questionnaire Survey, Procedia Manuf. 11 (2017).

[5] SAUCEDO-MARTÍNEZ, J.A., PÉREZ-LARA, M., MARMOLEJOSAUCEDO, J.A., SALAIS-FIERRO, T.E., PANDIAN, V. Industry 4.0 framework for management and operations. Journal of Ambient Intelligence and $\mathrm{Hu}-$ manized Computing June 2018, Volume 9. https://doi.org/10.1007/s12652-0170533-1.

[6] NEO - Núcleo de engenharia organizacional. Technology mapping. UFRGS,

2018.Available in:

http://abimaq.org.br/COMUNICACOES/2018/PROJETOS/DEPTOS/IPDMAQ/

Relatorio-Geral-Completo.pdf.

[7] MACDOUGALL, W. (2014). Industry 4.0 Smart Manufacturing for the Future. Germany Trade and Invest.

[8] BAUR, Cornelius; WEE, Dominik. Manufacturing's next act. McKinsey Quarterly, Jun 2015.

[9] FIRJAN - FEDERAÇÃO DAS INDÚSTRIAS DO ESTADO DO RIO DE JANEIRO. Industry 4.0 in Brazil: opportunities, perspectives and challenges / [Organizers : Firjan SENAI, Finep]. - Rio de Janeiro : [s.n], 2019.

[10] LORENZ, M.; KÜPPER, D.; RÜBMANN, M., HEIDEMANN, A. and BAUSE, A. Time to Accelerate in the Race Toward Industry 4.0, Boston Consulting Group, 2016.

[11] CNI - CONFEDERAÇÃO NACIONAL DA INDÚSTRIA. Industry 4.0. Special poll. Brasília, n. 66, May 2016.

[12] CNI - CONFEDERAÇÃO NACIONAL DA INDÚSTRIA - CNI. INDUSTRY 2027 Risks and Opportunities for Brazil in the face of disruptive innovations. Brasília:2018. 